\title{
Nutraceutical content and genetic diversity share a common pattern in new pomegranate genotypes
}

\author{
Carmen Arlotta, Valeria Toscano, Claudia Genovese*, Pietro Calderaro, Giuseppe Diego Puglia, Salvatore \\ Antonino Raccuia
}

Consiglio Nazionale delle Ricerche, Istituto per i Sistemi Agricoli e Forestali del Mediterraneo (CNR-ISAFOM) S.S. Catania, Via Empedocle, 58, 95128, Catania, Italy; arlottacarmen@gmail.com (C.A.); valeria.toscano@cnr.it (V.T.); pietro.calderaro@cnr.it (P.C.); giuseppediego.puglia@cnr.it (G.D.P.); salvatoreantonino.raccuia@cnr.it (S.A.R.)

* Correspondence: claudia.genovese@cnr.it (C.G.); Tel.: +39 0956139951

\begin{abstract}
The nutraceutical value of pomegranate in the treatment of many neoplastic, cardiovascular, viral, inflammatory, metabolic, microbial, intestinal, reproductive and skin diseases is well-documented and is linked to its richness in phenolic compounds. This study aims to evaluate nutraceutical and genetic diversity of novel pomegranate genotypes (G1-G5) in comparison to leading commercial pomegranate varieties i.e. 'Wonderful', 'Primosole', 'Dente di Cavallo' and 'Valenciana'. Morphometric measurements were carried out on fruits, accompanied by chemical characterization and the development of four new polymorphic SSR markers involved in the flavonoid pathway. The cultivars displayed a marked variability in the weight and shape of fruits, as well as in the weight of arils and juice yield. The highest level of total phenolic content and antioxidant activity was found in 'Wonderful' and G4, while the lowest was in 'Dente di Cavallo'. Furthermore, the results showed that the pomegranate juice, is an excellent source of minerals, especially potassium, which plays a key role in organ functioning. The new flavonoid-related markers effectively differentiated the cultivars with the same diversity pattern as morpho-chemical characterization, so the SSRs developed in the present study can be used as a rapid tool for the identification of pomegranate cultivars with relevant nutraceutical traits.
\end{abstract}

Keywords: Punica granatum L., Bio-agronomic traits, Antioxidant activity, Total phenolic content, Carbohydrates, Minerals, genetic diversity

\section{Introduction}

Punica granatum L. belongs to the Punicaceae family and it is an ancient and appreciated fruit crop. Pomegranate is a fruit tree widely grown in several countries, especially those with Mediterranean-like climates, characterized by high exposure to sunlight, mild winters with minimal temperatures not lower than $-12{ }^{\circ} \mathrm{C}$ and dry hot summers without rain during the last stages of the fruit development. Under such conditions, the fruit can develop to its best size and with an optimal colour and sugar accumulation without the danger of splitting [1]. Pomegranates have traditionally been used for the production of fresh juice from the arils, the edible parts of the fruit, but recently there is a great and increasing demand for industrial processing to obtain bottled juice, jams, oil, supplements and anti-ageing creams [2,3]. The juice represents on average the $30-40 \%$ of the total fruit weight and is a good source of minerals (potassium, phosphorus, calcium, iron and magnesium), as well as glucose, fructose [4] and fibres. Moreover, pomegranate juice contains organic acids (citric acid, malic acid), vitamin C, vitamin E, coenzyme $Q$ and polyphenols such as ellagitannins (punicalagin) and anthocyanins [5]. The juice concentration, the content of sugars, the colour, the polyphenol content and the quality of the product depending on the variety and degree of ripeness of fruits. Climatic and environmental conditions can influence these traits. Pomegranate 
varieties differ in their taste, ranging from sweet to sour, and this is related to the phenols, organic acids and sugars contained in the fruit. The most accepted varieties are those which have fruits with a more acidic flavour, rich in phenols with important health properties [6].

In recent years there has been an increase in pomegranate fruit production. Pomegranate berries are considered a functional product of great benefit for the human diet, due to the high nutraceutical content present in their juice. Hydrolysable tannins, anthocyanins, and minerals contained in them have useful health properties [2], such as cancer prevention and therapy [7], on chronic inflammatory diseases and cardiovascular diseases [8]. Beneficial effects and the antioxidant activity of the juice and fruit, in general, are attributed to the phenolic content that acts against free radicals, molecules highly harmful to the cells themselves. Moreover, today, the market demand comes from not only consumers, but also from many foods, nutraceutical and cosmetics companies, and for this reason, it has become increasingly important to characterize its different varieties to obtain high-quality products with economic interests.

In the last few years also in Italy, especially in the southern regions, there has been a rapid expansion of the areas cultivated with pomegranate that increased from 7 ha in 2008 to 1,303 ha in 2020 [9]. In Sicily pomegranate represents a minor fruit tree species even if it was cultivated since Arab domination, but it maintained great importance in private gardens and orchards until recent times. Thanks to uncontrolled sexual propagation that occurred from its introduction, nowadays many local genotypes can be found in Sicily, likely well adapted to different climate conditions from the sea up to $800 \mathrm{~m}$ above sea level [10]. Recent studies were aimed to unveil the mechanism for pomegranate flavonoids production and accumulation [11-13]. At the same time, several investigations were carried out on genetic variability screening thorough molecular markers i.e. SimpleSequence Repeat (SSR) allowing varietal identification [14-18]. However, all these studies relied only on neutral genes which are not linked to market valuable traits. Therefore, the development of non-neutral markers associated with relevant traits can be highly useful for the rapid identification of new potential valuable varieties and future breeding programs. To make the most of the potential beneficial effects of new pomegranate genotypes it is necessary to carry out wide-ranging research work of characterizing the various ecotypes. Many studies have been published on the evaluation of pomegranate germplasm using morphological, chemical and genetic variability, but an integrative approach integrating all these data would be beneficial for cultivar selection and improvement. In this study, an integrated morphological, chemical and molecular approach was used to characterize new pomegranate genotypes focusing on relevant nutraceutical traits, such as minerals and phenolic content.

\section{Results and Discussion}

\subsection{Pomological characteristics of fruits}

Morphological characteristics play an important role in consumer and market choice. Fruit size, aril yield and aril size are key traits for the fresh market and breeding programs. In this work, significant morphometric differences among studied genotypes were found. The average fruit weight found in this study was $413.96 \mathrm{~g}$ with high variability among genotypes ranging from $255.87 \mathrm{~g}$ in $\mathrm{G} 4$ to a maximum of $825.82 \mathrm{~g}$ observed in WD (Table 1). Variation of fruit weight could depend on the cultivar and ecological condition [3]. These data showed that as regards VL and WD, the average fruit weight was greater than reported in the literature [10,30], while the data of PS and DC were lower than reported by La Malfa [10].

Table 1. Morphologic characteristics of fruit and peel. 


\begin{tabular}{clcccccccc}
\hline Genotype & Fruit weight $(\mathbf{g})$ & $\begin{array}{c}\text { Fruit } \\
\text { circumference } \\
(\mathbf{m m})\end{array}$ & $\begin{array}{c}\text { Fruit } \\
\text { length } \\
(\mathbf{m m})\end{array}$ & $\begin{array}{c}\text { Fruit } \\
\text { diameter } \\
(\mathbf{m m})\end{array}$ & $\begin{array}{c}\text { Fruit } \\
\text { shape } \\
(\text { FL/FD) }\end{array}$ & $\begin{array}{c}\text { Septum } \\
\text { number }\end{array}$ & $\begin{array}{c}\text { Peel weight } \\
(\mathbf{g})\end{array}$ & $\begin{array}{c}\text { Peel yield } \\
(\%)\end{array}$ & $\begin{array}{c}\text { Dry peel } \\
\text { yield }(\%)\end{array}$ \\
\hline G1 & $285.72 \pm 28.61^{\mathrm{cd}}$ & $271.40 \pm 8.65^{\mathrm{e}}$ & $71.40 \pm 2.71^{\mathrm{d}}$ & $82.60 \pm 2.41^{\mathrm{de}}$ & $0.87 \pm 0.02^{\mathrm{a}}$ & $6.60 \pm 0.55^{\mathrm{b}}$ & $106.78 \pm 10.39^{\mathrm{d}}$ & $37.52 \pm 3.53^{\mathrm{c}}$ & $28.67 \pm 3.49^{\mathrm{cd}}$ \\
G2 & $385.92 \pm 29.97^{\mathrm{c}}$ & $303.20 \pm 10.24^{\mathrm{c}}$ & $79.64 \pm 1.68^{\mathrm{c}}$ & $98.08 \pm 8.55 \mathrm{c}$ & $0.82 \pm 0.07^{\mathrm{a}}$ & $6.60 \pm 0.55^{\mathrm{b}}$ & $162.15 \pm 17.11^{\mathrm{c}}$ & $41.10 \pm 2.22^{\mathrm{bc}}$ & $27.53 \pm 1.76^{\mathrm{d}}$ \\
G3 & $304.07 \pm 34.41^{\mathrm{cd}}$ & $276.00 \pm 10.84^{\mathrm{de}}$ & $74.40 \pm 2.31^{\mathrm{cd}}$ & $83.20 \pm 2.78^{\mathrm{de}}$ & $0.90 \pm 0.03^{\mathrm{a}}$ & $5.80 \pm 0.45^{\mathrm{b}}$ & $111.92 \pm 11.63^{\mathrm{d}}$ & $37.06 \pm 4.74^{\mathrm{c}}$ & $29.49 \pm 1.87^{\mathrm{cd}}$ \\
G4 & $255.87 \pm 23.26^{\mathrm{d}}$ & $263.00 \pm 7.88^{\mathrm{e}}$ & $70.24 \pm 2.57^{\mathrm{d}}$ & $80.64 \pm 3.74^{\mathrm{e}}$ & $0.88 \pm 0.04^{\mathrm{a}}$ & $7.00 \pm 1.00^{\mathrm{b}}$ & $121.95 \pm 22.29^{\mathrm{d}}$ & $47.76 \pm 8.64^{\mathrm{ab}}$ & $33.02 \pm 1.69^{\mathrm{ab}}$ \\
G5 & $632.42 \pm 105.24^{\mathrm{b}}$ & $362.00 \pm 21.68^{\mathrm{b}}$ & $90.74 \pm 3.00^{\mathrm{b}}$ & $106.44 \pm 6.09^{\mathrm{b}}$ & $0.86 \pm 0.04^{\mathrm{a}}$ & $8.20 \pm 0.45^{\mathrm{a}}$ & $295.72 \pm 40.29^{\mathrm{b}}$ & $47.27 \pm 6.11^{\mathrm{ab}}$ & $19.75 \pm 1.21^{\mathrm{e}}$ \\
PS & $297.85 \pm 54.84^{\mathrm{cd}}$ & $276.00 \pm 16.74^{\mathrm{cd}}$ & $67.60 \pm 2.41^{\mathrm{d}}$ & $82.40 \pm 3.58^{\mathrm{de}}$ & $0.83 \pm 0.02^{\mathrm{a}}$ & $6.20 \pm 0.45^{\mathrm{b}}$ & $117.74 \pm 16.10^{\mathrm{d}}$ & $40.07 \pm 6.06^{\mathrm{bc}}$ & $33.96 \pm 2.38^{\mathrm{ab}}$ \\
DC & $359.42 \pm 46.66^{\mathrm{cd}}$ & $295.00 \pm 11.73^{\mathrm{cd}}$ & $79.56 \pm 5.49^{\mathrm{c}}$ & $90.62 \pm 4.65^{\mathrm{d}}$ & $0.88 \pm 0.07^{\mathrm{a}}$ & $7.00 \pm 0.00^{\mathrm{b}}$ & $127.79 \pm 23.83^{\mathrm{d}}$ & $35.49 \pm 4.41^{\mathrm{c}}$ & $36.05 \pm 0.97^{\mathrm{a}}$ \\
VL & $378.51 \pm 28.24^{\mathrm{c}}$ & $297.60 \pm 3.37^{\mathrm{cd}}$ & $80.98 \pm 6.05^{\mathrm{c}}$ & $90.00 \pm 2.47^{\mathrm{d}}$ & $0.91 \pm 0.08^{\mathrm{a}}$ & $7.00 \pm 0.00^{\mathrm{b}}$ & $161.06 \pm 24.53^{\mathrm{c}}$ & $42.49 \pm 4.97^{\mathrm{bc}}$ & $31.28 \pm 2.91^{\mathrm{bc}}$ \\
WD & $825.83 \pm 142.80^{\mathrm{a}}$ & $386.00 \pm 19.62^{\mathrm{a}}$ & $105.05 \pm 8.61^{\mathrm{a}}$ & $114.65 \pm 5.18^{\mathrm{a}}$ & $0.92 \pm 0.06^{\mathrm{a}}$ & $6.75 \pm 1.50^{\mathrm{b}}$ & $430.34 \pm 70.61^{\mathrm{a}}$ & $52.24 \pm 3.02^{\mathrm{a}}$ & $20.97 \pm 1.54^{\mathrm{e}}$ \\
\hline
\end{tabular}

Data are expressed as mean \pm SD $(n=3)$. Significant differences $(\mathrm{P} \leq 0.05)$ are indicated by different letters. FL, Fruit lenght; FD, Fruit diameter; PS, 'Primosole'; DC, 'Dente di Cavallo'; VL, 'Valenciana'; WD, ‘Wonderful'.

Also, fruit circumference showed significant differences among genotypes which average was $303.35 \mathrm{~mm}$. WD and G5 showed the highest values $(386 \mathrm{~mm}$ and $362 \mathrm{~mm}$ respectively), while the lowest value was observed in G4 $(263 \mathrm{~mm})$. Accordingly, WD and G5 displayed also the highest fruit length and diameter values, while the lowest values were found in G4 and PS, as shown in Table 1. The average fruit size of WD grown in Sicily was greater than the WD cultivated in California as previously reported [30]. This could probably be due to the different climate, temperature and humidity conditions in the two environments. According to the fruit weight, WD also showed the highest weight of peel and arils (430.34 $\mathrm{g}$ and $395.48 \mathrm{~g}$ respectively) (Tables 1 and 2).

Table 2. Morphologic characteristics of arils and seeds.

\begin{tabular}{cccccccc}
\hline Genotype & $\begin{array}{c}\text { Number of } \\
\text { arils }\end{array}$ & $\begin{array}{c}\text { Arils weight } \\
\text { (g) }\end{array}$ & $\begin{array}{c}\text { Weight of } 100 \\
\text { arils (g) }\end{array}$ & $\begin{array}{c}\text { Arils yield } \\
(\%)\end{array}$ & $\begin{array}{c}\text { Dry arils } \\
\text { yield }(\%)\end{array}$ & $\begin{array}{c}\text { Seeds weight } \\
(\mathbf{g})\end{array}$ & $\begin{array}{c}\text { Seeds yield } \\
(\%)\end{array}$ \\
\hline G1 & $464 \pm 79.80^{\mathrm{bc}}$ & $178.94 \pm 25.61^{\mathrm{b}}$ & $39.98 \pm 1.96^{\mathrm{b}}$ & $62.48 \pm 3.54^{\mathrm{ab}}$ & $16.35 \pm 0.83^{\mathrm{d}}$ & $54.59 \pm 10.80^{\mathrm{c}}$ & $19.04 \pm 2.58^{\mathrm{ab}}$ \\
G2 & $568 \pm 50.23^{\mathrm{bc}}$ & $223.78 \pm 17.42^{\mathrm{b}}$ & $43.00 \pm 4.32^{\mathrm{b}}$ & $58.02 \pm 2.23^{\mathrm{abcd}}$ & $16.73 \pm 0.76^{\mathrm{cd}}$ & $80.42 \pm 3.89^{\mathrm{b}}$ & $20.90 \pm 1.21^{\mathrm{a}}$ \\
G3 & $479 \pm 107.12^{\mathrm{bc}}$ & $192.15 \pm 31.89^{\mathrm{b}}$ & $41.84 \pm 3.46^{\mathrm{b}}$ & $62.95 \pm 4.74^{\mathrm{ab}}$ & $17.17 \pm 0.87^{\mathrm{cd}}$ & $53.15 \pm 3.78^{\mathrm{c}}$ & $17.59 \pm 1.58^{\mathrm{abc}}$ \\
G4 & $372 \pm 87.48^{\mathrm{c}}$ & $133.92 \pm 26.77^{\mathrm{c}}$ & $38.76 \pm 4.3^{\mathrm{b}}$ & $52.24 \pm 8.64^{\mathrm{bcd}}$ & $17.97 \pm 0.26^{\mathrm{bc}}$ & $42.68 \pm 8.07^{\mathrm{c}}$ & $16.59 \pm 1.86^{\mathrm{bc}}$ \\
G5 & $674 \pm 146.24^{\mathrm{b}}$ & $336.70 \pm 85.89^{\mathrm{a}}$ & $50.87 \pm 1.86^{\mathrm{a}}$ & $52.73 \pm 6.12^{\mathrm{cd}}$ & $16.93 \pm 0.56^{\mathrm{cd}}$ & $123.63 \pm 22.48^{\mathrm{a}}$ & $19.54 \pm 1.34^{\mathrm{ab}}$ \\
PS & $510 \pm 158.46^{\mathrm{bc}}$ & $180.11 \pm 45.77^{\mathrm{b}}$ & $38.49 \pm 5.93^{\mathrm{b}}$ & $59.94 \pm 6.06^{\mathrm{abc}}$ & $18.99 \pm 1.27^{\mathrm{b}}$ & $46.29 \pm 9.00^{\mathrm{c}}$ & $15.66 \pm 2.85^{\mathrm{bc}}$ \\
DC & $550 \pm 78.25^{\mathrm{bc}}$ & $231.63 \pm 31.62^{\mathrm{b}}$ & $43.85 \pm 2.74^{\mathrm{b}}$ & $64.52 \pm 4.41^{\mathrm{a}}$ & $18.03 \pm 0.45^{\mathrm{bc}}$ & $57.32 \pm 5.81^{\mathrm{c}}$ & $16.02 \pm 1.17^{\mathrm{bc}}$ \\
VL & $543 \pm 104.58^{\mathrm{bc}}$ & $217.45 \pm 22.10^{\mathrm{b}}$ & $43.01 \pm 6.53^{\mathrm{b}}$ & $57.52 \pm 4.97^{\mathrm{abcd}}$ & $17.29 \pm 0.74^{\mathrm{cd}}$ & $50.60 \pm 14.03^{\mathrm{c}}$ & $13.44 \pm 4.16^{\mathrm{c}}$ \\
WD & $1028 \pm 219.96^{\mathrm{a}}$ & $395.48 \pm 80.39^{\mathrm{a}}$ & $38.60 \pm 3.42^{\mathrm{b}}$ & $47.77 \pm 3.02^{\mathrm{d}}$ & $23.08 \pm 0.51^{\mathrm{a}}$ & $118.51 \pm 34.84^{\mathrm{a}}$ & $14.19 \pm 2.16^{\mathrm{c}}$ \\
\hline
\end{tabular}

Data are expressed as mean $\pm \mathrm{SD}(\mathrm{n}=3)$. Significant differences $(\mathrm{P} \leq 0.05)$ are indicated by different letters. PS, 'Primosole'; DC, ‘Dente di Cavallo'; VL, 'Valenciana'; WD, 'Wonderful'.

The latter result was in agreement with the value reported for WD cultivar grown in Spain [30], but substantially differs from what obtained for the same cultivar grown in America [30] probably, once again, due to dissimilar environmental growth conditions. The value reported for arils weight of our VL (217.45 g) was lower than reported by Alcaraz-Mármol [31].

Because of the ready-to-eat arils are attracting increasing international demand, due to their health and nutraceutical characteristics the arils features determine the economic value of the fruit and are important parameters for growers, market and industry [32]. The genotypes studied showed a large variability on arils traits: DC showed the highest arils yield (64.52\%), while the lowest was observed in WD (47.77\%); but also, two Sicilian 
genotypes, G1 and G3 displayed high arils yield (62.48\% and $62.95 \%$ respectively). Furthermore, G5 genotype has been shown to have the biggest arils with a weight of 100 arils equal to $50.87 \mathrm{~g}$, instead, PS and WD have been shown the lowest $(38.49 \mathrm{~g}$ and 38.60 $\mathrm{g}$ respectively).

Also, the peel thickness is one important trait of market selection; fruits with thin skin and therefore with a lower peel yield, are more suitable for processing, while those with a thicker skin and higher peel yield are more suitable for transport and storage and can therefore be used for fresh consumption [3]. About peel, on the contrary to what was observed for arils yield, WD genotype showed the highest peel yield $(52.24 \%)$ while DC was the lowest $(35.49 \%)$, showing that arils and peels yields are inversely correlated. However, the dry arils yield was highest in WD (23.08\%), while dry peel yield was found to be highest in DC (36.05\%), indicating that the percentage of humidity in these fruits, for the parameters analysed, is lower than the other cultivars examined.

\subsection{Juice characteristics}

The juice yield is a very important trait from an industrial point of view to obtain bottled juice. According to the highest aril yield DC showed also the highest juice yield with $48.50 \%$ (Table 3), instead G5 and WD showed the lower value with $33.18 \%$ and $33.58 \%$ respectively. In general, G1-G5 genotypes showed values of yield in arils and in juice higher or similar compared to the international genotypes (VL and WD). This classifies G1-G5 accessions as good products for the market and juice production.

Table 3. Physico-chemical characteristics of juice.

\begin{tabular}{|c|c|c|c|c|c|c|c|c|c|}
\hline Genotype & $\begin{array}{c}\text { Juice weight } \\
\text { (g) }\end{array}$ & Juice yield (\%) & $\mathrm{pH}$ & $\begin{array}{c}\text { Total } \\
\text { soluble } \\
\text { solids ( }{ }^{\circ} \text { Brix) } \\
\end{array}$ & $\begin{array}{c}\text { Lightness } \\
\left(\mathrm{L}^{*}\right)\end{array}$ & Color a* & Color b* & $\begin{array}{c}\text { Chroma } \\
\left(C^{*}\right)\end{array}$ & Hue $\left(h^{\circ}\right)$ \\
\hline G1 & $124.34 \pm 16.87^{\mathrm{cd}}$ & $43.43 \pm 2.47^{\mathrm{abc}}$ & $3.63 \pm 0.08^{\mathrm{ab}}$ & $16.06 \pm 0.19 \mathrm{bc}$ & $17.70 \pm 0.93^{\mathrm{b}}$ & $6.84 \pm 0.67^{\mathrm{bc}}$ & $-1.62 \pm 0.43^{c}$ & $7.05 \pm 0.58^{\mathrm{bc}}$ & $-13.51 \pm 4.39 c$ \\
\hline G2 & $143.35 \pm 15.72^{\mathrm{cd}}$ & $37.12 \pm 2.57^{\mathrm{bcd}}$ & $3.76 \pm 0.10^{\mathrm{a}}$ & $15.76 \pm 0.63^{c}$ & $17.77 \pm 0.80^{\mathrm{b}}$ & $5.86 \pm 0.60^{c}$ & $-1.70 \pm 0.19 c$ & $6.11 \pm 0.58^{\mathrm{bc}}$ & $-16.27 \pm 2.19^{c}$ \\
\hline G3 & $139.00 \pm 30.61^{\mathrm{cd}}$ & $45.35 \pm 6.10^{\mathrm{ab}}$ & $3.77 \pm 0.08^{\mathrm{a}}$ & $16.06 \pm 0.58^{\mathrm{bc}}$ & $22.40 \pm 4.05^{\mathrm{a}}$ & $10.49 \pm 3.42^{\mathrm{a}}$ & $4.49 \pm 1.47^{\mathrm{a}}$ & $11.21 \pm 3.02^{\mathrm{a}}$ & $25.06 \pm 8.27 \mathrm{a}$ \\
\hline G4 & $91.23 \pm 20.76^{\mathrm{d}}$ & $35.64 \pm 7.47 \mathrm{~cd}$ & $3.54 \pm 0.06^{\mathrm{b}}$ & $17.00 \pm 0.37 \mathrm{ab}$ & $18.69 \pm 1.33^{\mathrm{ab}}$ & $10.93 \pm 1.47^{a}$ & $2.52 \pm 3.52^{\mathrm{ab}}$ & $11.51 \pm 2.51^{\mathrm{a}}$ & $10.82 \pm 13.15^{b}$ \\
\hline G5 & $213.06 \pm 64.13^{b}$ & $33.18 \pm 5.34^{\mathrm{d}}$ & $3.15 \pm 0.05^{c}$ & $16.08 \pm 0.51^{b c}$ & $21.06 \pm 5.51^{\mathrm{ab}}$ & $10.68 \pm 3.37^{a}$ & $4.36 \pm 1.94^{\mathrm{a}}$ & $11.40 \pm 4.07^{\mathrm{a}}$ & $19.36 \pm 7.84^{\mathrm{ab}}$ \\
\hline PS & $133.81 \pm 40.00^{\mathrm{cd}}$ & $44.27 \pm 5.39 \mathrm{abc}$ & $3.72 \pm 0.07^{\mathrm{a}}$ & $17.52 \pm 0.85^{\mathrm{a}}$ & $18.57 \pm 0.27^{\mathrm{ab}}$ & $8.75 \pm 1.10^{\mathrm{ab}}$ & $-1.33 \pm 0.09^{b}$ & $8.81 \pm 1.09^{\mathrm{ab}}$ & $-8.60 \pm 1.20^{c}$ \\
\hline $\mathrm{DC}$ & $174.31 \pm 26.58^{\mathrm{bc}}$ & $48.50 \pm 3.78^{a}$ & $3.64 \pm 0.03^{\mathrm{ab}}$ & $17.54 \pm 0.21^{\mathrm{a}}$ & $18.07 \pm 1.78^{\mathrm{b}}$ & $6.66 \pm 1.03^{\mathrm{bc}}$ & $-0.83 \pm 1.01^{c}$ & $6.78 \pm 0.95^{\mathrm{bc}}$ & $-7.70 \pm 9.23^{c}$ \\
\hline VL & $166.85 \pm 20.15^{\mathrm{bc}}$ & $44.08 \pm 4.11^{\mathrm{abc}}$ & $3.67 \pm 0.10^{\mathrm{ab}}$ & $17.58 \pm 0.60^{\mathrm{a}}$ & $19.59 \pm 1.50^{\mathrm{ab}}$ & $4.88 \pm 1.34^{\mathrm{c}}$ & $-1.59 \pm 0.64^{c}$ & $5.19 \pm 1.19 c$ & $-19.30 \pm 9.41^{c}$ \\
\hline WD & $276.98 \pm 51.18^{a}$ & $33.58 \pm 2.57 \mathrm{~d}$ & $3.14 \pm 0.20^{c}$ & $17.75 \pm 0.86^{\mathrm{a}}$ & $13.59 \pm 0.74^{c}$ & $7.08 \pm 1.67 \mathrm{bc}$ & $1.30 \pm 0.37 \mathrm{bc}$ & $7.20 \pm 1.71 \mathrm{bc}$ & $10.32 \pm 1.15^{\mathrm{b}}$ \\
\hline
\end{tabular}

Data are expressed as mean $\pm \mathrm{SD}(\mathrm{n}=3)$. Significant differences $(\mathrm{P} \leq 0.05)$ are indicated by different letters. PS, 'Primosole'; DC, 'Dente di Cavallo'; VL, 'Valenciana'; WD, ‘Wonderful'.

Determination of total soluble solids (TSS or ${ }^{\circ}$ Brix) is important to establish the organoleptic quality of the juice. The range of ${ }^{\circ}$ Brix values found was from 15.76 in G2 to 17.75 in WD, all varieties tested had a ${ }^{\circ}$ Brix value higher than the minimum threshold generally required for commercial use $(>12 \%)$. Our values are similar to those found in previous studies on different Apulian, Spanish and Californian pomegranate genotypes $[17,30,31]$. The value obtained for WD was higher than that reported by the same previous studies but this may be due to environmental conditions and harvesting time.

The highest $\mathrm{pH}$ value was measured for G2, G3 and PS while the lowest was for G5 and WD. These $\mathrm{pH}$ values were in agreement with Ferrara [17] and Beaulieu [33] for WD and with Todaro [34] for PS, DC and VL, growth in the experimental farm of the Catania University (Italy, Sicily), but they were lower than reported by Alcaraz-Mármol [31] for WD and DC.

It was observed also differences among juice colour in the genotypes (Table 3), G3 showed the highest values of lightness of colour $\left(\mathrm{L}^{*}\right)(22.40)$, whereas WD showed the 
lowest (13.47, 13.59 and 14.63 respectively). The highest values of colour a* (tending to red colour) were observed in G4 (10.93), while G3 (4.49) and G5 (4.36) showed the greatest value of colour $b^{*}$, which means that the juice colour tends to be yellow. As regard value $\mathrm{C}^{*}$ it was observed that G3, G4 and G5 were the genotypes with the most intensity/purity of the colour with values of 11.21, 11.51 and 11.40 respectively. In addition, for the value of $h^{\circ}$ significant differences were found between cultivars, a very high value was found in G3 (25.06). According to the CIELAB colour parameters cultivars with values of colour, $a^{*}$ positive and colour $b^{*}$ negative have pigmentation from red to blue (G1, G2, PS, DC and VL), while cultivars with values of colour $a^{*}$ and colour $b^{*}$ positives have pigmentation from red to yellow (G3, G4, G5, and WD). Moreover, VL showed the lowest value of colour $\mathrm{a}^{*}, \mathrm{C}^{*}$ and $\mathrm{h}^{\circ}$, which means that its juice tends towards a clear pink colour.

\subsection{Total phenolic content and antioxidant activity}

Total phenolic content ranged from 645.59 (in DC) to $1447.22 \mathrm{mg} \mathrm{L}^{-1}$ (in WD) (Figure 1A). The average value of TPC was $884.83 \mathrm{mg} \mathrm{L}^{-1}$ showing to be significantly influenced by the genotype $(\mathrm{P} \leq 0.05)$. In particular, among the tested genotypes, the $\mathrm{G} 4$ showed the highest phenolic content (1203.77 $\left.\mathrm{mg} \mathrm{L}^{-1}\right)$, comparable to the WD (1447.22 $\left.\mathrm{mg} \mathrm{L}^{-1}\right)$, which is the most studied international genotype. While, the genotypes with lower values were DC, G5 and VL. The values obtained were similar to those reported by Fanali [35] for the six old Italian pomegranate varieties collected in the experimental farm of Tuscia University (range from 500 to $1400 \mathrm{mg} \mathrm{GAE} \mathrm{L}^{-1}$ ). In comparison with previous literature data, Sicilian genotypes often showed TPC lower than some Croatian cultivars [36] and higher values than some Iranian pomegranates [37].
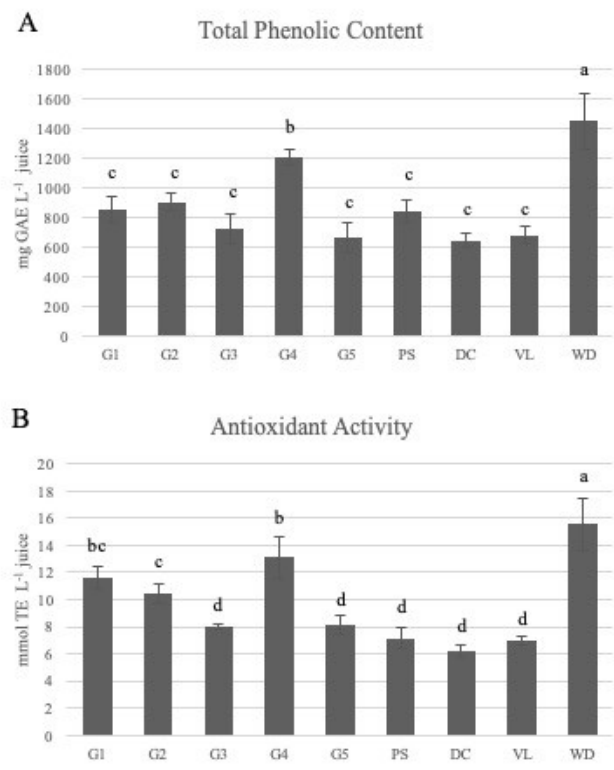

Figure 1. Total Phenolic Content (A) and Antioxidant Activity (B) in pomegranate juices. Each value is the mean of three replicates and is reported with standard deviation. Value bars indicated with different letters are significantly different $(\mathrm{P} \leq 0.05)$.

The antioxidant activity followed the same trend of the TPC with the mean value of $9.69 \mathrm{mmol} \mathrm{L}^{-1}$, varying significantly $(\mathrm{P} \leq 0.05)$ between 6.24 in DC and 15.56 in WD (Figure 1B). WD showed the highest AA followed by G4. The WD and VL values in this study were similar to those reported by Mena [38] for the same cultivars grown in Spain (commercially available accessions).

The AA and TPC levels were positively and significantly correlated $(r=0.974)$. 


\subsection{Quantitative determination of Carbohydrates by HPAE-PAD}

The main carbohydrates detected in juices were glucose and fructose (Table 4).

Table 4. Carbohydrate content $\left(\mathrm{g} \mathrm{L}^{-1}\right)$ of pomegranate juices.

\begin{tabular}{cllcc}
\hline Genotype & Glucose $(G)$ & Fructose $(\mathbf{F})$ & Total & Ratio G/F \\
\hline G1 & $45.33 \pm 0.79^{\mathrm{de}}$ & $33.54 \pm 0.39^{\mathrm{de}}$ & 78.87 & 1.35 \\
G2 & $64.16 \pm 0.09^{\mathrm{a}}$ & $68.90 \pm 0.24^{\mathrm{a}}$ & 133.06 & 0.93 \\
G3 & $43.18 \pm 1.20^{\mathrm{ef}}$ & $32.03 \pm 0.80^{\mathrm{e}}$ & 75.20 & 1.35 \\
G4 & $46.21 \pm 2.29^{\mathrm{d}}$ & $34.44 \pm 1.54^{\mathrm{d}}$ & 80.65 & 1.34 \\
G5 & $36.83 \pm 0.96^{\mathrm{g}}$ & $27.84 \pm 0.63^{\mathrm{g}}$ & 64.67 & 1.32 \\
PS & $48.69 \pm 0.28^{\mathrm{c}}$ & $35.51 \pm 0.15^{\mathrm{d}}$ & 84.20 & 1.37 \\
DC & $52.81 \pm 1.16^{\mathrm{b}}$ & $38.36 \pm 1.36^{\mathrm{c}}$ & 91.17 & 1.38 \\
VL & $40.96 \pm 2.62^{\mathrm{f}}$ & $29.89 \pm 1.72^{\mathrm{f}}$ & 70.85 & 1.37 \\
WD & $62.54 \pm 0.23^{\mathrm{a}}$ & $62.50 \pm 0.04^{\mathrm{b}}$ & 125.04 & 1.00 \\
\hline
\end{tabular}

Data are expressed as mean \pm SD $(n=3)$. Significant differences $(P \leq 0.05)$ are indicated by different letters. PS, 'Primosole'; DC, 'Dente di Cavallo'; VL, 'Valenciana'; WD, 'Wonderful'.

The glucose concentration was mainly greater than fructose, with the ratio glucose/fructose taking values from 0.93 in G2 to 1.38 in DC. Similar profiles were previously described for other cultivars [39,40], one of which was PS. In contrast, it is reported that the Spanish genotypes have almost always higher levels of fructose than glucose [41] as reported for WD and VL grown in Spain [30,37].

In this work, G2 showed the highest carbohydrate content followed by WD. In particular, the highest amount of glucose was detected in G2 and in WD with $64.16 \mathrm{~g} \mathrm{~L}^{-1}$ and $62.54 \mathrm{~g} \mathrm{~L}^{-1}$ respectively, the lowest in $\mathrm{G} 5$ with $36.83 \mathrm{~g} \mathrm{~L}^{-1}$. A similar trend was for fructose with G2 which showed also the highest amount of fructose $\left(68.90 \mathrm{~g} \mathrm{~L}^{-1}\right)$, while G5 was the lowest $\left(27.84 \mathrm{~g} \mathrm{~L}^{-1}\right)$. Sugar profile contributes to potential health benefits and determines the sensory attributes of pomegranate; juice red pomegranate cultivars usually have a sourer taste than pink-white genotypes. Figure 2 shows the chromatogram of one of the PJs (DC).

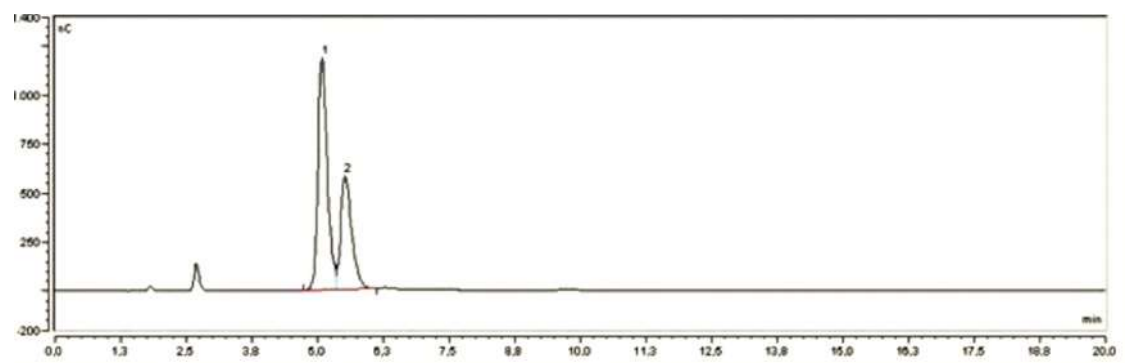

Figure 2. HPAE-PAD chromatogram of pomegranate juice (DC). Glucose (1) and fructose (2).

\subsection{Quantitative determination of Minerals by IC}

The minerals in pomegranate juice, shown in Table 5, varied significantly among the genotypes. The highest content of macro-elements present in all samples of juices was potassium (1816.73 $\left.\mathrm{mg} \mathrm{L}^{-1}\right)$, followed by chlorides $\left(416.90 \mathrm{mg} \mathrm{L}^{-1}\right)$ and phosphates (367.04 $\mathrm{mg} \mathrm{L}^{-1}$ ), according to Al-Maiman and Ahmad [42] who reported potassium as the highest among the mineral elements in pomegranate juice.

Table 5. Minerals $\left(\mathrm{mg} \mathrm{L}^{-1}\right)$ of pomegranate juices. 


\begin{tabular}{|c|c|c|c|c|c|c|c|c|c|c|}
\hline Parameter & G1 & G2 & G3 & G4 & G5 & PS & DC & VL & WD & Mean \\
\hline \multicolumn{11}{|l|}{ Anions (A-) } \\
\hline Fluorides & $42.97 \pm 1.52^{\mathrm{e}}$ & $41.80 \pm 0.72^{\mathrm{e}}$ & $48.27 \pm 1.33^{c}$ & $45.60 \pm 1.52^{\mathrm{d}}$ & $41.67 \pm 0.29 \mathrm{e}$ & $39.03 \pm 1.22^{\mathrm{f}}$ & $59.90 \pm 0.61^{\mathrm{a}}$ & $42.37 \pm 0.42^{\mathrm{e}}$ & $51.33 \pm 0.75^{\mathrm{b}}$ & 45.88 \\
\hline Chlorides & $365.17 \pm 7.88^{f}$ & $296.07 \pm 2.02^{\mathrm{h}}$ & $317.63 \pm 2.87 \mathrm{~g}$ & $380.83 \pm 3.86^{e}$ & $285.70 \pm 1.04^{\mathrm{h}}$ & $489.63 \pm 7.94^{c}$ & $637.10 \pm 12.00^{a}$ & $422.00 \pm 1.67 \mathrm{~d}$ & $557.97 \pm 6.33^{b}$ & 416.90 \\
\hline Phosphates & $262.80 \pm 5.95^{\mathrm{h}}$ & $333.40 \pm 3.95^{\mathrm{d}}$ & $310.87 \pm 7.49^{f}$ & $294.47 \pm 4.91 \mathrm{~g}$ & $317.17 \pm 2.72^{\mathrm{e}}$ & $387.67 \pm 0.61^{c}$ & $463.87 \pm 8.28^{b}$ & $387.80 \pm 0.36^{c}$ & $545.30 \pm 8.31^{\mathrm{a}}$ & 367.04 \\
\hline Sulphates & $69.53 \pm 0.40^{\mathrm{i}}$ & $83.70 \pm 1.51^{\mathrm{g}}$ & $113.20 \pm 1.45^{\mathrm{d}}$ & $90.93 \pm 2.01^{\mathrm{f}}$ & $139.97 \pm 1.40^{\mathrm{b}}$ & $126.60 \pm 0.44^{c}$ & $206.73 \pm 3.23^{\mathrm{a}}$ & $93.97 \pm 1.21^{\mathrm{e}}$ & $79.60 \pm 1.47^{\mathrm{h}}$ & 111.58 \\
\hline Total A- & 740.47 & 754.97 & 789.97 & 811.83 & 784.51 & 1042.93 & 1367.60 & 946.14 & 1234.20 & \\
\hline \multicolumn{11}{|l|}{ Cations $(\mathrm{C}+)$} \\
\hline Sodium & $9.21 \pm 0.92^{\mathrm{e}}$ & $13.33 \pm 0.49^{c}$ & $13.58 \pm 0.24^{c}$ & $12.81 \pm 0.31^{\mathrm{cd}}$ & $11.70 \pm 1.05^{\mathrm{d}}$ & $14.08 \pm 0.14^{c}$ & $18.53 \pm 1.69^{a}$ & $16.09 \pm 0.88^{\mathrm{b}}$ & $18.84 \pm 0.86^{\mathrm{a}}$ & 14.24 \\
\hline Potassium & $1710.42 \pm 19.95^{\mathrm{d}}$ & $1819.33 \pm 13.83^{c}$ & $1679.56 \pm 68.23^{d}$ & $1287.99 \pm 70.45^{\mathrm{e}}$ & $2056.63 \pm 19.41^{b}$ & $1668.04 \pm 0.56^{d}$ & $2142.66 \pm 16.43^{b}$ & $1749.37 \pm 28.68^{\mathrm{d}}$ & $2236.56 \pm 51.49^{a}$ & 1816.73 \\
\hline Magnesium & $54.32 \pm 1.26^{c}$ & $57.57 \pm 0.54^{\mathrm{b}}$ & $72.08 \pm 3.02^{\mathrm{a}}$ & $53.98 \pm 2.81^{\mathrm{c}}$ & $69.58 \pm 0.61^{\mathrm{a}}$ & $49.00 \pm 1.02^{\mathrm{d}}$ & $70.60 \pm 0.73^{a}$ & $48.75 \pm 0.93^{\mathrm{d}}$ & $57.84 \pm 1.85^{\mathrm{b}}$ & 59.30 \\
\hline Calcium & $8.66 \pm 1.69^{c}$ & $7.67 \pm 1.06^{c}$ & $6.98 \pm 0.40^{c}$ & $8.05 \pm 0.69^{c}$ & $30.38 \pm 1.20^{\mathrm{b}}$ & $7.29 \pm 0.53^{c}$ & $9.95 \pm 1.18^{c}$ & $8.15 \pm 1.60^{c}$ & $36.93 \pm 1.20^{\mathrm{a}}$ & 13.78 \\
\hline Total C+ & 1782.61 & 1897.90 & 1772.20 & 1362.83 & 2168.29 & 1738.41 & 2241.74 & 1822.36 & 2350.17 & \\
\hline $\begin{array}{l}\text { Total } \\
\text { Minerals }\end{array}$ & 2523.08 & 2652.87 & 2562.17 & 2174.66 & 2952.80 & 2781.34 & 3609.34 & 2768.50 & 3584.37 & \\
\hline
\end{tabular}

Data are expressed as mean $\pm \mathrm{SD}(\mathrm{n}=3)$. Significant differences $(\mathrm{P} \leq 0.05)$ are indicated by different letters. PS, 'Primosole'; DC, 'Dente di Cavallo'; VL, 'Valenciana'; WD, 'Wonderful'.

Concerning anions (Figure 3A), the highest values were found in the genotype DC (1367.6 mg L-1) followed by WD (1234.20 mg L-1). Lower values were generally found in the Sicilian genotypes, especially in G1 $\left(740.47 \mathrm{mg} \mathrm{L}^{-1}\right)$. The relative order of concentration of anions was $\mathrm{Cl}^{-}>\mathrm{PO}_{4}{ }^{3-}>\mathrm{SO}_{4}{ }^{2-}>\mathrm{F}^{-}$. The content of chlorides, sulphates and fluorides was greater in DC, whereas the content of phosphates in WD.

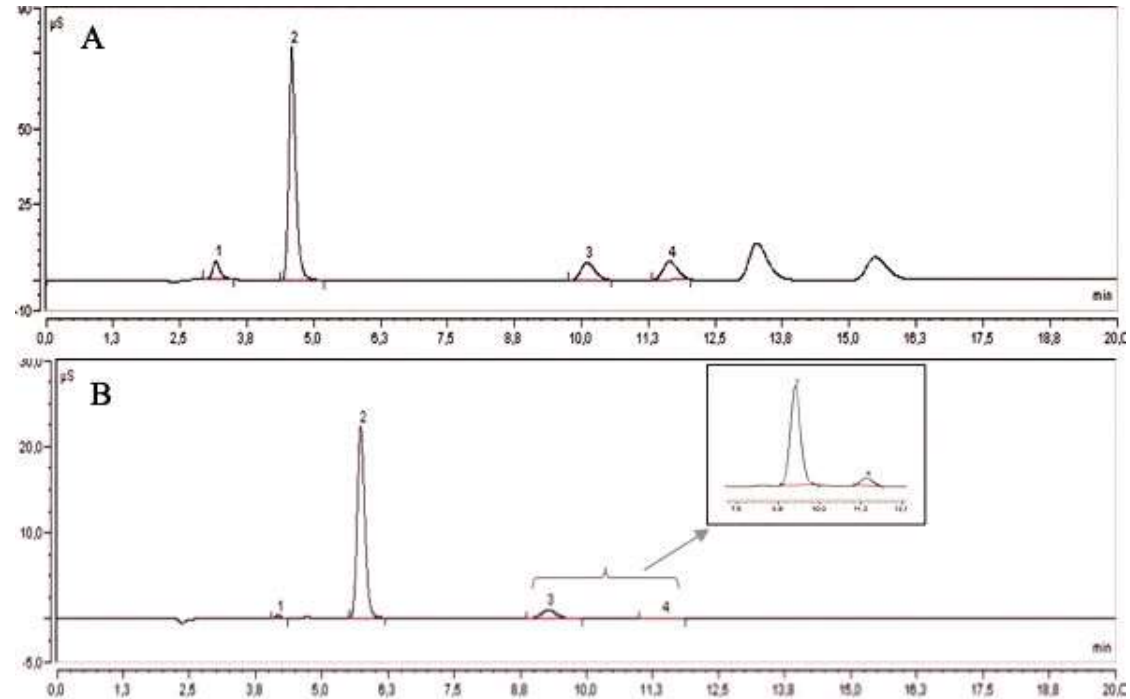

Figure 3. IC chromatogram of pomegranate juice (DC). Fluorides (1), chlorides (2), phosphates (3) and sulfates (4) (A). Sodium (1), potassium (2), magnesium (3) and calcium (4) (B).

Regarding cations (Figure 3B) the greatest results were generally found in WD (2350.17 $\left.\mathrm{mg} \mathrm{L}^{-1}\right)$ and DC (2241.74 $\left.\mathrm{mg} \mathrm{L}^{-1}\right)$, the lowest value was in G4 (1362.84 $\left.\mathrm{mg} \mathrm{L}^{-1}\right)$. The order of concentration of cations was $\mathrm{K}^{+}>\mathrm{Mg}^{2+}>\mathrm{Na}^{+}>\mathrm{Ca}^{2+}$ similar to that found by Al- 
Maiman and Ahmad [42] in 'Taifi' cultivars, except for the magnesium which was lower. Potassium, sodium and calcium were predominant in WD, whereas magnesium in G3. Overall, among the genotypes analysed DC and WD showed the highest concentration of minerals, 3609.34 and $3584.37 \mathrm{mg} \mathrm{L}^{-1}$ respectively. The pomegranate juice appears to be a good source of nutrients and variation in mineral composition could originate from the pomegranate genotypes as well as agro-climatic conditions, handling practices and manufacturing conditions.

\subsection{Molecular analyses}

Molecular analyses performed using SSRs produced a total of 96 alleles, with maximum number of alleles per locus ranging from 4 to 14 and a length of the amplified bands between $130 \mathrm{bp}$ to $367 \mathrm{bp}$ (Figure 4).
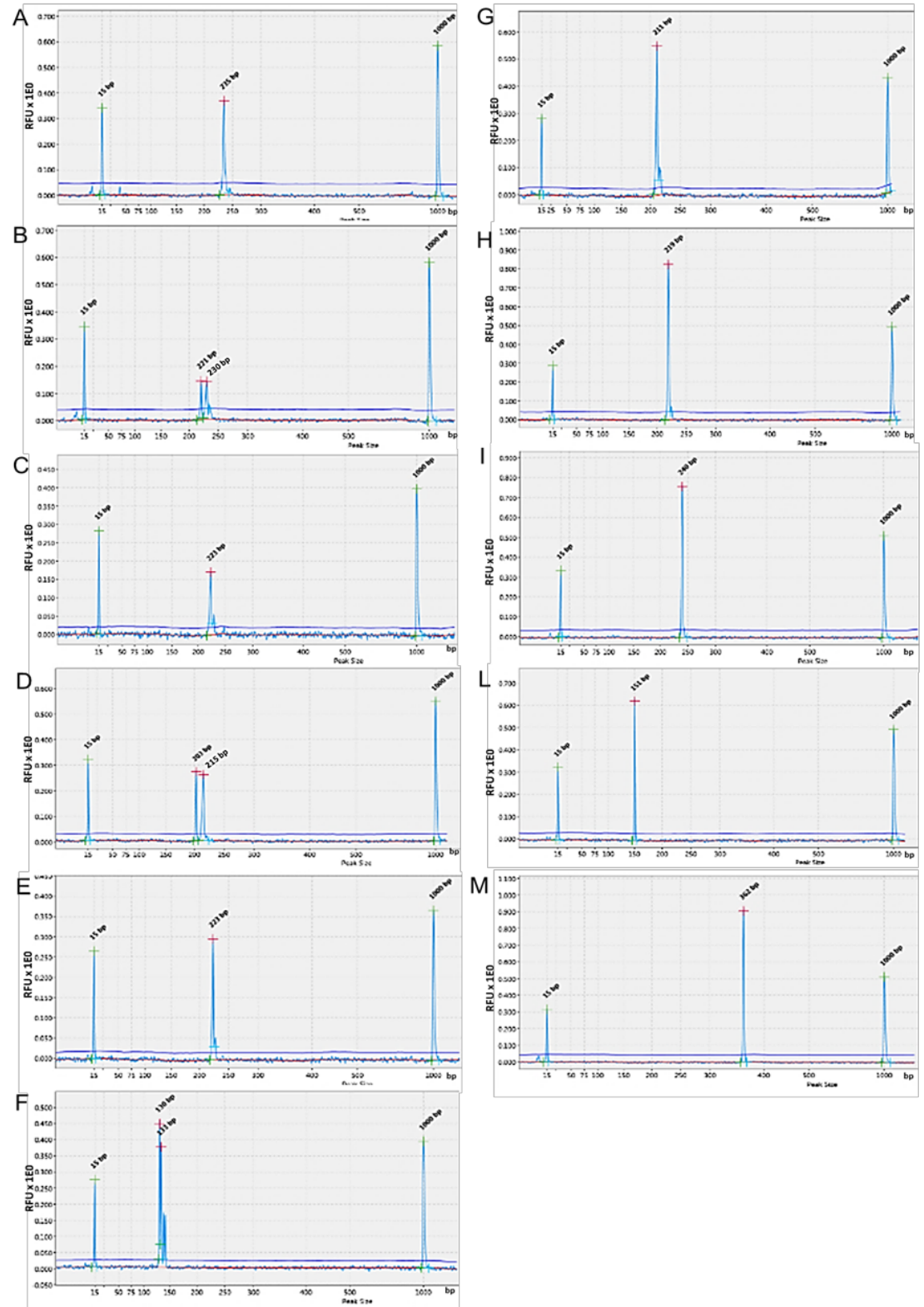

Figure 4. Capillary electrophoresis run of the PCR amplification products of 'Wonderful' (WD) variety with literature derived ones Pg4 (A), Pg10 (B), Pg14 (C), Pg21 (D), Pg22 (E), Pg17 (F), Pom047 (G) and new developed markers MYBmp01 (H), MYBmp02 (I), MYBmp03 (L), MYBmp04 (M) and 
MYB derived markers were always homozygous, while Pg17, Pg21 and Pg10 were heterozygous. Peaks at 15 and 1000 bp correspond to the alignment marker used in the analysis.

The PIC was used to measure genetic diversity. High, medium or low loci polymorphism is in accordance with $\mathrm{PIC}>0.5,0.5>\mathrm{PIC}>0.25$ and $\mathrm{PIC}<0.25$, respectively [27]. A high PIC for all the markers used in this study was observed, on average 0.753, ranging from 0.469 of pg4 to 0.891 of pg14 (Table 6) higher than the previous analysis with the same microsatellites [24,27]. Among the new microsatellite markers developed in this study, MYBmp04 and MYBmp01 displayed a very high variability among the studied genotypes with PIC values of 0.875 and 0.775 respectively (Table 6).

Table 6. Microsatellite allele data obtained using 11 polymorphic microsatellite loci in the tested pomegranate genotypes.

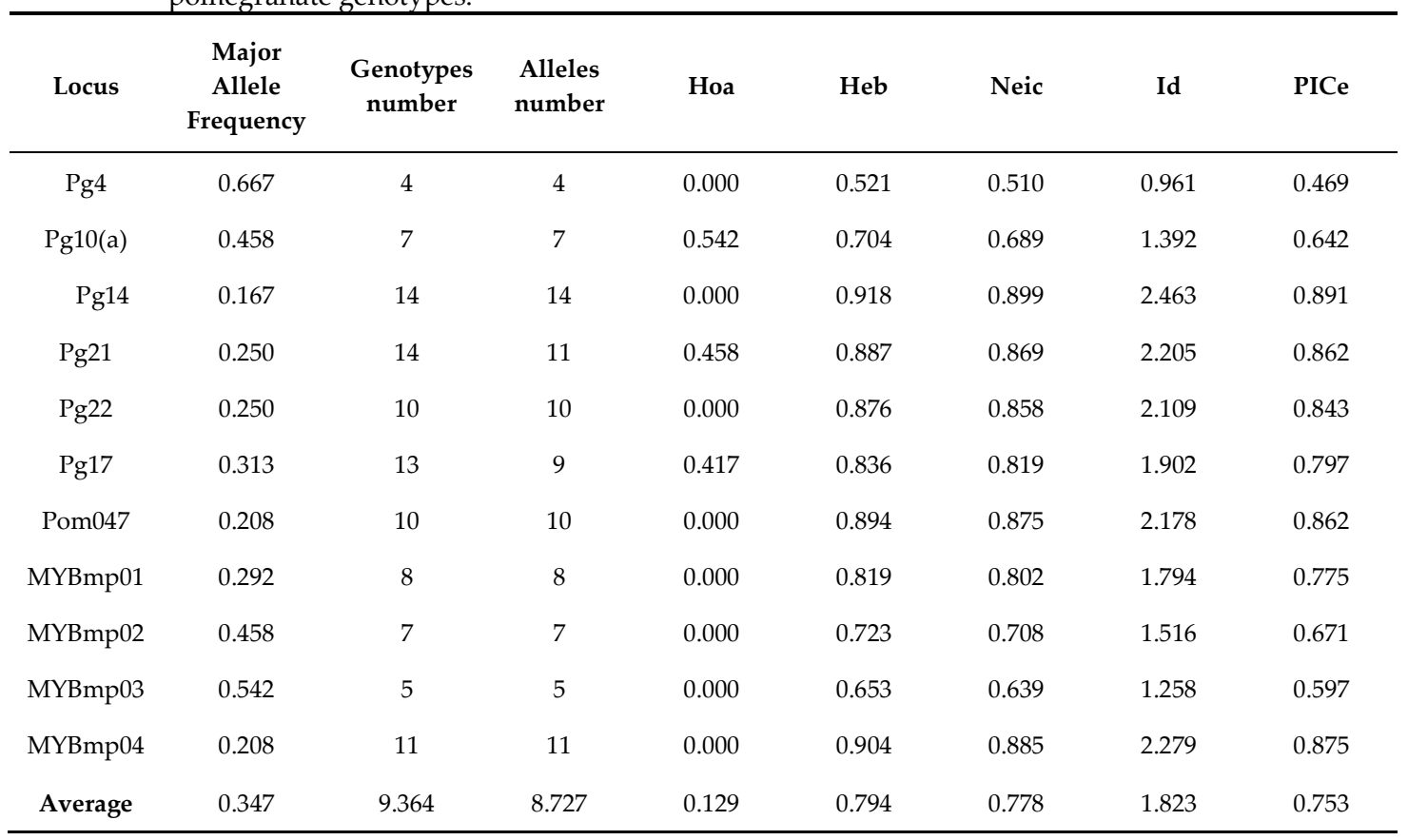

a Observed heterozygosity; ${ }^{\mathrm{b}}$ Expected heterozygosity; ${ }^{\mathrm{c}}$ Effective number of alleles; ${ }^{\mathrm{d}}$ Shannon's Information index; e Polymorphism Information Content.

Although with a less degree, MYBmp02 and MYBmp03 markers showed relevant variability and all of them could be recommended for further genetic analyses aimed at detecting molecular diversity in pomegranate germplasm collection. Shannon index (I), the number of effective alleles $(\mathrm{Ne})$ and heterozygosity $(\mathrm{He})$ values were consistent with the PIC trend. The Nei's genetic diversity and Shannon's information index in Sicilian pomegranates in the present study were higher in comparison to Indian pomegranates, based on ISSR markers reported by Narzary [43]. It can be shown that the SSR marker is a trustworthy technique for assessing genetic diversity in pomegranate genotypes. The average number of alleles was 8.727 which is significantly higher with respect to what was reported for Iranian pomegranate genotypes analysed with chloroplast SSRs [44] and even with respect to previous analyses with nuclear microsatellites as well [24,45]. This set of 4 new MYB-related SSRs along with the other 7 SSRs might be useful for population genetic analyses, such as genotyping and linkage mapping.

Cluster UPGMA analysis (Figure 5) performed with all 11 microsatellites clustered the tested genotypes into 3 main groups and showed that there is a genetic differentiation among the international genotypes. 


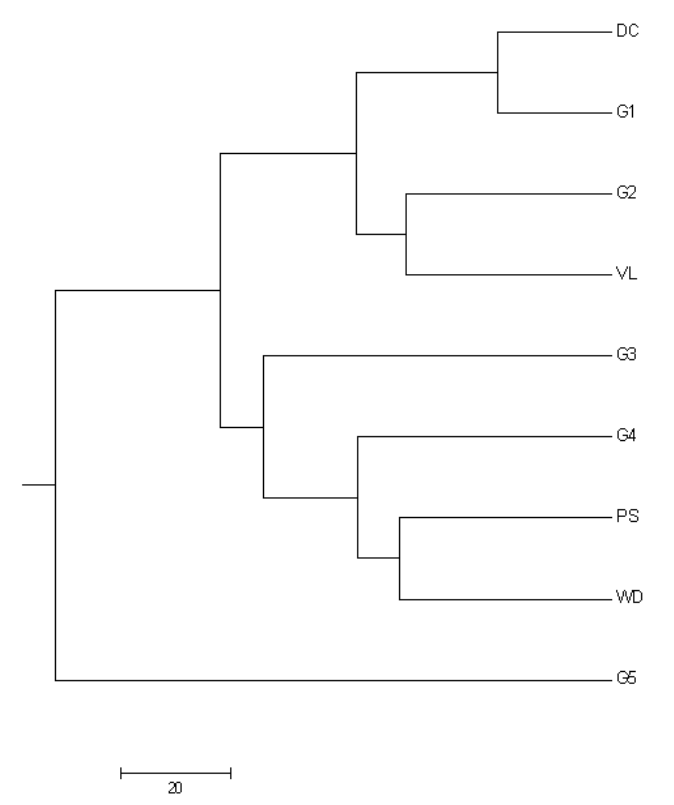

Figure 5. UPGMA dendrogram of 9 pomegranate genotypes based on the nuclear microsatellite (SSR) markers described in Table 6.

The first one was composed of DC, G1, G2 and VL while the second one included G3, G4, PS and WD. On the other hand, G5 was distinctly separated, forming an outgroup, from all the other tested varieties. DC and G1 clustered together also G4 and G3, WD and PS, in general, are closely related, while VL showed association with G1-G5 genotypes in particular with G1, G2 and DC. The affinity between VL and the most of G1-G5 genotypes could be due to a common genetic origin since they have been domesticated within the Mediterranean basin; similarly, the clustering of PS together with WD could be explained by a common genetic matrix between the two as shown by Parvaresh [27] referring to "Palermo" genotype. This different clusterization of the two international commercial varieties could have arisen from the highly different phenolic compounds composition between WD and VL as reported along with this study.

\subsection{Principal component analysis}

The selection of the most valuable fruit characteristics as weight, shape (circumference), juice ${ }^{\circ}$ Brix, juice $\mathrm{pH}$, juice colour, aril weight, aril yield, juice yield, minerals (as cations and anions) and antioxidant activity allowed to identify a specific differentiation pattern in which G1-G4, 'Valenciana' and 'Primosole' are closely related, while DC, G5 and WD were apart from the group and between each other (Figure 6A). 
A

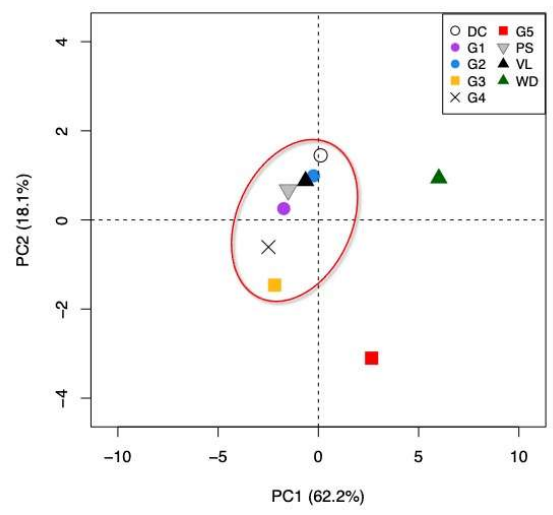

B

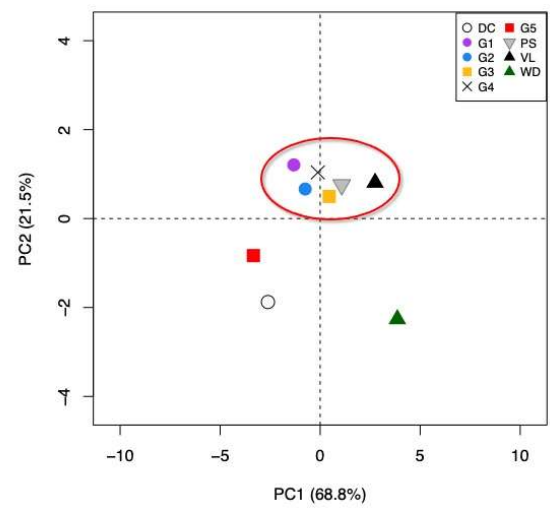

Figure 6. Principal component analysis of the sampled genotypes using morphological and physicochemical characters (A) and four non-neutral SSRs (B). Represented values are the mean of 5 individual measurements.

Total variability of morphological and chemical factors is described by four factors, with the first two principal factors explaining $74.4 \%$. The first factor accounted for $53.1 \%$ while the second one contributed by $21.3 \%$. The PCA on molecular data (Figure $6 \mathrm{~B}$ ) revealed the same clustering pattern to the morpho-chemical one; in fact, the G1-G4 genotypes were grouped and G5, WD and DC were more isolated. The total genetic variability is described by four factors with the first two principal factors explaining 90.3\%. Differently from the result of UPGMA elaboration, the use of microsatellites derived from MYB related genes allowed a more efficient separation of genotypes reproducing the morpho-chemical characteristics. The Mantel test showed that flavonoidassociated SSR Euclidean distances were significantly correlated with morpho-chemical traits among the sampled genotypes $(\mathrm{r}=0.62, \mathrm{P}<0.05)$. This finding could represent a valid tool to rapidly analyse the technological characteristics, such as fruit shape and weight, minerals content, juice features and antioxidant properties, of new pomegranate genotypes using genetic markers.

\section{Materials and Methods}

\subsection{Plant material}

The sampling was carried on fruits and leaves of five pomegranate Sicilian genotypes, from 'Genotype 1' to 'Genotype 5' (from G1 to G5), two Sicilian commercial cultivars 'Primosole'(PS) and 'Dente di Cavallo' (DC) and two international world-leading commercial varieties 'Valenciana'(VL) and 'Wonderful'(WD), collected in Sicily in October 2016 (Figure 7). All cultivars were harvested from a germplasm collection of CNR-ISAFOM, the section of Catania (Italy), grown under the same environmental conditions and with the same applied agronomic practices. For each accession, five fruits at the marketing ripeness stage were randomly collected. 


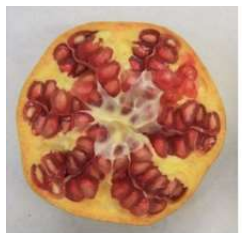

G1

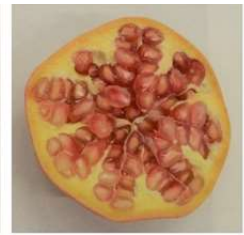

G2

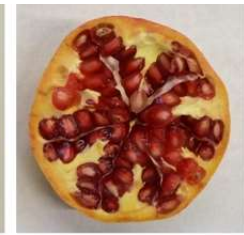

G3

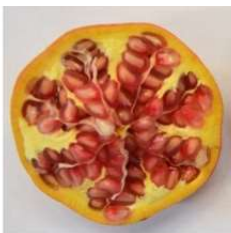

G4

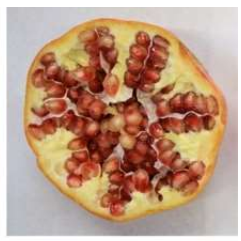

G5

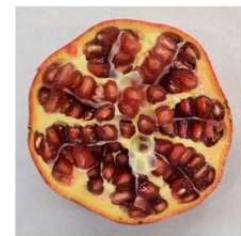

Primosole

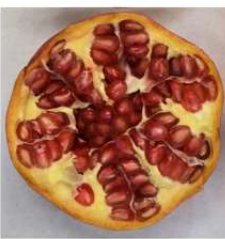

Dente di Cavallo

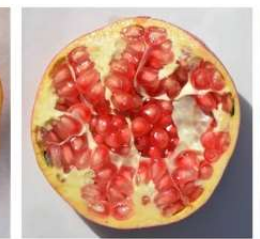

Valenciana

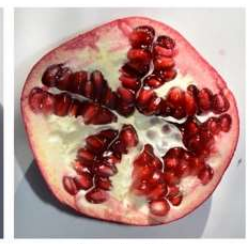

Wonderful

Figure 7. Cross section of pomegranate genotypes studied in this work.

\subsection{Chemicals}

Folin-Ciocalteau, sodium carbonate, 2,2-diphenyl-1-picrylhydrazyl (DPPH), methanol, 6-hydroxy-2,5,7,8-tetramethylchroman-2-carboxylic acid (Trolox), fructose, glucose, sodium hydroxide $50 \%$ and standard solutions for IC $1000 \mathrm{mg} \mathrm{L}^{-1}$ of sodium, potassium, magnesium, calcium, fluoride, chloride, sulphate and phosphate were purchased from Sigma-Aldrich (St. Louis, MO, USA). Methanesulphonic acid, sodium carbonate $0.5 \mathrm{M}$ and sodium bicarbonate $0.5 \mathrm{M}$ were obtained from Thermo Scientific (Waltham, Massachusetts, USA). Gallic acid was provided by Extrasynthese (Genay, France). Water Type I reagent grade was produced using a Milli-Q water purification system (Millipore, MA, USA).

\subsection{Bio-agronomic traits and physico-chemical analysis}

Five mature fruits per genotype were analysed. Arils were manually separated from the peel and morphometric measurements were carried out on different fruit organs: peel, arils and seeds. Eighteen quantitative fruit morphological traits were examined, including fruit weight (g), fruit diameter $(\mathrm{mm})$, fruit length $(\mathrm{mm})$, fruit circumference $(\mathrm{mm})$, number of septa, number of arils per fruit, arils weight (g), the weight of 100 arils per fruit (g), seeds weight $(\mathrm{g})$, peel weight $(\mathrm{g})$, juice weight $(\mathrm{g})$. From these data, the peel yield $(\%)$, arils yield (\%), juice yield (\%) and seeds yield (\%) were calculated. Furthermore, peel and arils were dried for $48 \mathrm{~h}$ at $105{ }^{\circ} \mathrm{C}$ and dry peel and arils yield (\%) were determined. The pomegranate juice (PJ) was obtained by manual squeezing of arils through sterile gauze. The PJ was separated into aliquots and some juice was immediately frozen at $-20{ }^{\circ} \mathrm{C}$ for downstream analyses. On the fresh juice, the following analyses were carried out: total soluble solids (TSS), $\mathrm{pH}$ and colour. The TSS was determined with a digital refractometer DBR 45 (Giorgio Bormac S.r.l., Carpi, Italy) and results were reported as ${ }^{\circ}$ Brix at $20{ }^{\circ} \mathrm{C}$. The $\mathrm{pH}$ measurements were performed using a digital $\mathrm{pH}$ meter XS Instruments mod. PC510 at $20^{\circ} \mathrm{C}$. The colour was measured with a Chroma Meter CR-400 (Konica Minolta, Osaka, Japan) using the CIELAB colour system [19]. Three colour measurements were made $\left(L^{*}, a^{*}, b^{*}\right)$ and chroma $\left(C^{*}\right)$ and hue $\left(h^{\circ}\right)$ units of colour space were detected.

\subsection{Total Phenolic Content}

The Total Phenolic Content (TPC) was determined by the method of Dewanto [20], with some modifications. The PJ, appropriately diluted with ultrapure water, was centrifuged at $5000 \mathrm{rpm}$ for $4 \mathrm{~min}$ and $125 \mu \mathrm{L}$ of supernatant was mixed with $625 \mu \mathrm{L}$ of Folin-Ciocalteu reagent 5-fold-diluted with ultrapure water. After $6 \mathrm{~min}, 1.25 \mathrm{~mL}$ of $7 \%$ $\mathrm{Na}_{2} \mathrm{CO}_{3}$ aqueous solution and $1 \mathrm{~mL}$ of ultrapure water were added. The mixture was shaken and placed in the dark at room temperature for 1 hour. After incubation, the total content of phenolic compounds was measured at $760 \mathrm{~nm}$ using the BioSpectrometer UV/Vis spectrophotometer (Eppendorf, Hamburg, Germany). Gallic acid standard 
solution (25-200 $\left.\mathrm{mg} \mathrm{L}^{-1}\right)$ was used for the calibration curve $(\mathrm{R} 2=0.9943)$. All measurements were performed in triplicate. The results were expressed as $\mathrm{mg}$ of gallic acid equivalent per litre of juice (mg GAE L-1).

\subsection{Antioxidant activity}

The antioxidant activity (AA) of PJ was determined using the DPPH method described by Brand-Williams [21] with some modifications. PJ diluted in the ratio of 1:100 with methanol was centrifuged at $5000 \mathrm{rpm}$ for $4 \mathrm{~min}$. Afterwards, $100 \mu \mathrm{L}$ of supernatant was mixed with $2 \mathrm{~mL}$ of $0.1 \mathrm{mM}$ DPPH in methanol. After incubating at room temperature for $30 \mathrm{~min}$ in the dark, the absorbance of the mixture was measured at $517 \mathrm{~nm}$. Trolox was used as a reference (calibration range $\left.10-200 \mu \mathrm{mol} \mathrm{L}^{-1} ; \mathrm{R}^{2}=0.9992\right)$. All samples were analysed in triplicates and the results are expressed as mmol Trolox per litre of juice (mmol TE L-1).

\subsection{Quantitative determination of Carbohydrates by HPAE-PAD}

The quantification of the main carbohydrates (fructose and glucose) present in PJ was determined by the method of Corradini [22]. PJ, diluted in the ratio 1:1000 with deionized water and filtered $(0.45 \mu \mathrm{m})$, was analysed using a High-Performance Anion-Exchange chromatography with Pulsed Amperometric Detection (HPAE-PAD), Thermo Scientific Dionex ICS3000 (Sunnyvale, CA, USA), consisting in a quaternary gradient inert pump, a pulsed amperometric detector and AS40 automated sampler. The separation was carried out on a Dionex CarboPac PA10 analytical column (250x4 mm i.d.). The acquisition of all the chromatograms was performed with Chromeleon Chromatography Management System. All experiments were carried out at $30^{\circ} \mathrm{C}$ under isocratic elution using $\mathrm{NaOH} 100$ $\mathrm{mM}$ with a flow-rate of $0.8 \mathrm{~mL} \mathrm{~min}^{-1}$. All analyses were performed in triplicate for each agronomic sample, quantified by calibration curve (range $0.5-100 \mathrm{mg} \mathrm{L}^{-1} ; \mathrm{R}^{2}=0.9982$ for glucose and $\mathrm{R}^{2}=0.9995$ for fructose) and the results are reported in $\mathrm{mg} \mathrm{L}^{-1}$. Relative standard deviations (RSD \%) of peak retention times were $<0.8 \%$.

\subsection{Quantitative determination of Minerals by IC}

The mineral content was determined using the ion chromatography (IC) method [23]. The most important inorganic anionic and cationic constituents of PJ were analysed: $\mathrm{F}$, $\mathrm{Cl}-\mathrm{PO}_{4}{ }^{3-}$ and $\mathrm{SO}_{4}{ }^{2-}$ for anions, $\mathrm{Na}^{+}, \mathrm{K}^{+}, \mathrm{Mg}^{2+}$ and $\mathrm{Ca}^{2+}$ for cations.

PJ was diluted in the ratio 1:100 with deionized water, filtered with a syringe filter $0.45 \mu \mathrm{m}$ and subjected to analysis. All chromatographic analyses were performed by a Thermo Scientific Dionex ICS3000 ion chromatography (Sunnyvale, CA, USA) composed of an isocratic pump, a cationic or anionic suppressor, a conductance detector equipped with a temperature compensated conductivity cell, an injection valve with a $25 \mu \mathrm{L}$ loop and a column thermostat compartment. The ion separation was carried out with two ionexchange columns: anions were separated on a Dionex IonPac AS22 column (250x4 mm i.d.) with an IonPac AG22 guard column (50x4 mm i.d.) and cations were determined using an IonPac CS12A column (250x4 mm i.d.) equipped with IonPac CG12A guard column (50x4 mm i.d.).

An aqueous solution containing $20 \mathrm{mM}$ methanesulfonic acid was used for the elution of cations. The mobile phase containing $4.5 \mathrm{mM}$ sodium carbonate and $1.4 \mathrm{mM}$ sodium bicarbonate was used for the elution of anions. Flow rate of $1.0 \mathrm{~mL} \mathrm{~min}^{-1}$ and 1.2 $\mathrm{mL} \mathrm{min}^{-1}$ was used for the separation of cations and anions respectively, maintaining the column temperature at $30^{\circ} \mathrm{C}$ during analysis. All analyses were performed in triplicate for each agronomic sample, quantified by calibration curve (range $0.5-100 \mathrm{mg} \mathrm{L}^{-1} ; \mathrm{R}^{2}>$ 0.999 ) and the results are reported in $\mathrm{mg} \mathrm{L}^{-1}$ of juice. Relative standard deviations (RSD \%) of peak retention times ranged from $0.7 \%$ to $2.1 \%$.

\subsection{Molecular analyses}


Genomic DNA was extracted from $100 \mathrm{mg}$ of leaf pomegranate using the CTAB method described by Ebrahimi [24]. Samples quantity and quality were assessed by checking them on a $1 \%$ agarose gel and by measuring with an Eppendorf BioSpectrometer ${ }^{\circledR}$ (Eppendorf AG, Hamburg, Germany) their absorbance at $260 \mathrm{~nm}$ and $280 \mathrm{~nm}$ to assess DNA purity.

Sixty-four loci characterized in previous studies [16,24-28] were considered for the analysis of genetic relationships among cultivars. Out of 64 loci, 7 markers were selected based on heterozygosity, the number of alleles, allele size and amplification reproducibility, preferring tetra- and tri-nucleotides compared to di-nucleotides. Furthermore, 4 new gene-derived primer pairs were designed using putative Punica granatum MYB gene sequences (GenBank Acc. num. HM056531.1 and MT495437.1) involved in the biosynthesis of flavonoids as reported in Arlotta [12] (Table 7).

Table 7. Primer sets used to investigate genetic diversity among pomegranate cultivars and the annealing temperature $(\mathrm{Ta})$ chosen for each primer.

\begin{tabular}{|c|c|c|c|c|}
\hline Locus & Repeat motif & Primer sequence (5'-3') & $\mathrm{Ta}{ }^{\circ} \mathrm{C}$ & Reference \\
\hline $\operatorname{Pg} 4$ & (TC)12 TT(TC)20 & $\begin{array}{l}\text { F: CTGATGTAATGGCTGAGCAAA } \\
\text { R: GCACTTGAACAAAGAGAATGC }\end{array}$ & 63 & Ebrahimi et al. 2010 \\
\hline Pg10(a) & (AG)9 GG(AG)14 & $\begin{array}{l}\text { F: TGCTAGACAGAACTGGGAGAAC } \\
\text { R: AGAGAGTGGGGTTTCCATTG }\end{array}$ & 63 & Ebrahimi et al. 2010 \\
\hline Pg14 & (AG)32 & $\begin{array}{l}\text { F: GCACATTTCTTCCACСТTCC } \\
\text { R: GGTTACAATGCACAGAGTCCAC }\end{array}$ & 62 & Ebrahimi et al. 2010 \\
\hline Pg21 & $(\mathrm{AG}) 7$ & $\begin{array}{l}\text { F: CAAGACAGAAGCACCATCCA } \\
\text { R: TCTCCCAAATCAGACCAACC }\end{array}$ & 62 & Ebrahimi et al. 2010 \\
\hline Pg22 & $(\mathrm{ACAT}) 3(\mathrm{AT}) 3(\mathrm{AG}) 22(\mathrm{AT}) 3$ & $\begin{array}{l}\text { F: CCCCGCACTTAGAATCTATTA } \\
\text { R: TCCAGTTCCAATCGACAGAC }\end{array}$ & 56 & Ebrahimi et al. 2010 \\
\hline Pg17 & (TCA) 14 & $\begin{array}{l}\text { F: CATCAGACTACGATGGCACT } \\
\text { R: GCATAATAGCCTTCAATTTACA }\end{array}$ & 57 & Parvaresh et al. 2010 \\
\hline Pom047 & $(\mathrm{CT}) 24$ & $\begin{array}{l}\text { F: GCCTATCTCGTGATCACATC } \\
\text { R: AATGGGAGCGGACTAACTAT }\end{array}$ & 57 & Rania et al. 2012 \\
\hline MYBmp01 & $(\mathrm{CT}) 9$ & $\begin{array}{l}\text { F: GATGAAGATGACAAAACACCCC } \\
\text { R: TGGGAGCTAGACAGAGTGACAA }\end{array}$ & 60 & Present study \\
\hline MYBmp02 & (GA)12 & $\begin{array}{l}\text { F: TCCTCAAGCAGACCCAGAAA } \\
\text { R: TGCTGTTCTTGTTACGCCTT }\end{array}$ & 62 & Present study \\
\hline MYBmp03 & (AGC)4 & $\begin{array}{l}\text { F: AGGCGTAACAAGAACAGCAA } \\
\text { R: AGCAACAGTCTTCCACСTCC }\end{array}$ & 62 & Present study \\
\hline MYBmp04 & (GAG)4 & $\begin{array}{l}\text { F: CTCGCTTGTCTTGCTAAAGGAT } \\
\text { R: CGAGGAACTTATTGACCCACTC }\end{array}$ & 57 & Present study \\
\hline
\end{tabular}

DNA was diluted to $30 \mathrm{ng} \mathrm{L}^{-1}$ for PCR amplification. PCR assays were performed in a reaction mixture of $25 \mu \mathrm{L}^{-1}$ including: $90 \mathrm{ng}$ of genomic DNA, $0.25 \mu \mathrm{M}$ of each primer, $200 \mu \mathrm{M}$ dNTPs, 1 U of Q5 High-Fidelity DNA polymerase (Biolabs, New England) and 4 $\mu \mathrm{L}^{-1}$ of $5 \mathrm{x}$ Q5 Reaction Buffer. DNA amplifications were performed in a thermocycler with the following cycling program: an initial denaturation step of $98^{\circ} \mathrm{C}$ for $30 \mathrm{~s}$, followed by 30 cycles of $98^{\circ} \mathrm{C}$ for $10 \mathrm{~s}$, at optimal annealing temperature for $30 \mathrm{~s}, 72^{\circ} \mathrm{C}$ for $30 \mathrm{~s}$ and a final extension at $72{ }^{\circ} \mathrm{C}$ for $2 \mathrm{~min}$. The amplification results were analysed by Capillary Electrophoresis using QIAxcel High Resolution Gel Cartridge (Qiagen, Hilden, Germany).

GeneALEx version 6.5 [29] was used to obtain a pairwise population matrix calculated through Nei's genetic distance, while expected heterozygosity $(\mathrm{He})$, observed 
heterozygosity (Ho), number effective alleles (Ne), Shannon index (I), the number of alleles and UPGMA dendrogram were calculated along with the number of alleles, major allele frequency, number of genotypes and polymorphism information content (PIC) value for each primer.

\subsection{Statistical analysis}

All analyses were carried out in triplicate and data were expressed as mean \pm standard deviation. Pearson correlation coefficient ( $r$ ) in bivariate linear correlation followed by Student's test was used to compare phenolic content and antioxidant activity. Differences between means at the $95 \%(P \leq 0.05)$ confidence level were considered statistically significant.

All data were submitted to Bartlett's test for the homogeneity of variance and the data that were not homogeneous were logarithmically transformed. All the homogeneous data were analysed using analysis of variance (ANOVA) by CoSTAT program.

Two different Principal Component Analysis (PCA) were performed to evaluate the potentiality of identified genetic markers. In the first PCA we used morphological and chemical traits: arils weight, peel weight, juice weight, seed weight, fruit circumference, ${ }^{\circ}$ Brix, juice $\mathrm{pH}$, colour L* , chroma, TPC, AA, minerals (as cations and anions) and sugars. While another PCA was performed using only SSRs associated with flavonoid production. A Mantel test was performed to measure the correlation between the two matrices from each PCA as Euclidean distance matrices based on 9999 replications. Data were analysed using the $\mathrm{R}$ environment for statistical computing ( $\mathrm{R}$ Development Core Team, 2021).

\section{Conclusions}

This study evaluated new pomegranate genotypes using leading commercial varieties as reference. A significant variability has been observed for the qualitative and chemical traits among the pomegranate genotypes. The SSR markers used in this study were suitable for the assessment of variability in pomegranate germplasm for the preservation of this species. Moreover, the $M Y B$-related markers might represent a promising tool for rapid genetic characterization of pomegranate accessions focused on marketable traits. Furthermore, all the microsatellite markers evaluated in the present study confirmed the relationships observed with morphological and chemical characteristics and can be used as genetic tools for breeding purposes.

As regards the nutraceutical content, the results showed that the pomegranate juice is an excellent source of minerals, essential for human health. Consuming a fruit per day, indeed, may cover the daily requirement of many minerals, especially potassium. Moreover, G4 presented the highest total phenolic content and antioxidant activity, even higher than the well-known marketable 'Dente di Cavallo', 'Valenciana' and 'Primosole'. The G1-G3 and G5 genotypes presented a value of total phenolic content and antioxidant activity comparable to the commercial ones, representing a valid alternative to the most common cultivars for nutraceutical purposes.

Author Contributions: Conceptualization, S.A.R.; methodology, C.A., V.T., C.G., G.D.P. and S.A.R.; validation, C.A., V.T., C.G., G.D.P. and S.A.R.; formal analysis, C.A., V.T., C.G. and G.D.P.; investigation, C.A., V.T., C.G., G.D.P. and P.C.; resources, S.A.R. and P.C.; data curation, C.A., V.T., C.G. and G.D.P.; writing - original draft preparation, C.A., V.T., C.G. and G.D.P.; writing-review and editing, C.G., V.T. and G.D.P.; supervision, S.A.R.; funding acquisition, S.A.R. All authors have read and agreed to the published version of the manuscript.

Funding: This research received no external funding.

Informed Consent Statement: Not applicable.

Data Availability Statement: Not applicable. 
Acknowledgments: The authors kindly thank Helena Domenica Pappalardo and Giusi D'Amante for helping in fruit harvesting and processing.

Conflicts of Interest: The authors declare no conflict of interest.

Sample Availability: Samples of the compounds are not available from the authors.

\section{References}

1. Holland, D., Hatib, K., \& Bar-Ya'akov, I. Pomegranate: Botany, Horticulture, Breeding. Horticultural Reviews, 2009. $127-191$.

2. Khadivi, A., Ayenehkar, D., Kazemi, M., \& Khaleghi, A. Phenotypic and pomological characterization of a pomegranate (Punica granatum L.) germplasm collection and identification of the promising selections. Scientia horticulturae, 2018, 238, 234-245.

3. Melgarejo-Sánchez, P., Martínez, J. J., Legua, P., Martínez, R., Hernández, F., \& Melgarejo, P. Quality, antioxidant activity and total phenols of six Spanish pomegranates clones. Scientia Horticulturae, 2015, 182, 65-72.

4. Tezcan, F., Gültekin-Özgüven, M., Diken, T., Özçelik, B., \& Erim, F. B. Antioxidant activity and total phenolic, organic acid and sugar content in commercial pomegranate juices. Food Chemistry, 2009, 115(3), 873-877.

5. Topalović, A., Knežević, M., Gačnik, S., \& Mikulic-Petkovsek, M. Detailed chemical composition of juice from autochthonous pomegranate genotypes (Punica granatum L.) grown in different locations in Montenegro. Food Chemistry, 2020, 330, 127261

6. Cristofori, V., Caruso, D., Latini, G., Dell'Agli, M., Cammilli, C., Rugini, E., ... \& Muleo, R. Fruit quality of Italian pomegranate (Punica granatum L.) autochthonous varieties. European Food Research and Technology, 2011, 232(3), $397-403$.

7. Tibullo, D., Caporarello, N., Giallongo, C., Anfuso, C., Genovese, C., Arlotta, C., ...\& Raccuia, S. Antiproliferative and Antiangiogenic Effects of Punica granatum Juice (PGJ) in Multiple Myeloma (MM). Nutrients, 2016, 8(10), 611.

8. Vlachojannis, C., Erne, P., Schoenenberger, A. W., \& Chrubasik-Hausmann, S. A critical evaluation of the clinical evidence for pomegranate preparations in the prevention and treatment of cardiovascular diseases. Phytotherapy research, 2015, 29(4), 501-508.

9. ISTAT. Available online: http://dati.istat.it/index.aspx?queryid=33705

10. La Malfa, S., Gentile, A., Domina, F., \& Tribulato, E. Primosole: a new selection from Sicilian pomegranate germplasm. Acta Horticulturae, 2009, (818), 125-132.

11. Ben-Simhon, Z., Judeinstein, S., Nadler-Hassar, T., Trainin, T., Bar-Ya'akov, I., Borochov-Neori, H., \& Holland, D. A pomegranate (Punica granatum L.) WD40-repeat gene is a functional homologue of Arabidopsis TTG1 and is involved in the regulation of anthocyanin biosynthesis during pomegranate fruit development. Planta, 2011, 234(5), 865-881.

12. Arlotta, C., Puglia, G. D., Genovese, C., Toscano, V., Karlova, R., Beekwilder, J., ... Raccuia, S. A. MYB5-like and bHLH influence flavonoid composition in pomegranate. Plant Science, 2020, 298, 110563

13. Trainin, T., Harel-Beja, R., Bar-Ya'akov, I., Ben-Simhon, Z., Yahalomi, R., Borochov-Neori, H., ... Holland, D. Fine Mapping of the "black" Peel Color in Pomegranate (Punica granatum L.) Strongly Suggests That a Mutation in the Anthocyanidin Reductase (ANR) Gene Is Responsible for the Trait. Frontiers in Plant Science, 2021, 12.

14. Hasnaoui, N., Buonamici, A., Sebastiani, F., Mars, M., Zhang, D., \& Vendramin, G. G. Molecular genetic diversity of Punica granatum L. (pomegranate) as revealed by microsatellite DNA markers (SSR). Gene, 2012, 493(1), 105-112.

15. Ono, N. N., Britton, M. T., Fass, J. N., Nicolet, C. M., Lin, D., \& Tian, L. Exploring the Transcriptome Landscape of Pomegranate Fruit Peel for Natural Product Biosynthetic Gene and SSR Marker DiscoveryF. Journal of Integrative Plant Biology, 2011, 53(10), 800-813.

16. Currò, S., Caruso, M., Distefano, G., Gentile, A., \& La Malfa, S. New microsatellite loci for pomegranate, Punica granatum (Lythraceae). American Journal of Botany, 2010, 97(7), e58-e60.

17. Ferrara, G., Giancaspro, A., Mazzeo, A., Giove, S. L., Matarrese, A. M. S., Pacucci, C., ... Gadaleta, A. Characterization of pomegranate (Punica granatum L.) genotypes collected in Puglia region, Southeastern Italy. Scientia Horticulturae, 2014, $178,70-78$.

18. Tarantino, A., Difonzo, G., Disciglio, G., Frabboni, L., Paradiso, V. M., Gambacorta, G., \& Caponio, F. Fresh pomegranate juices from cultivars and local ecotypes grown in southeastern Italy: comparison of physicochemical properties, antioxidant activity and bioactive compounds. Journal of the Science of Food and Agriculture, 2021.

19. Moss, J. R., \& Otten, L. A relationship between colour development and moisture content during roasting of peanuts. Canadian Institute of food science and technology journal, 1989, 22(1), 34-39.

20. Dewanto, V., Wu, X., Adom, K. K., \& Liu, R. H. Thermal processing enhances the nutritional value of tomatoes by increasing total antioxidant activity. Journal of Agricultural and Food Chemistry, 2002, 50(10), 3010-3014.

21. Brand-Williams, W., Cuvelier, M. E., \& Berset, C. Use of a free radical method to evaluate antioxidant activity. LWT - Food Science and Technology, 1995, 28(1), 25-30. 
22. Corradini, C., Cavazza, A., \& Bignardi, C. High-performance anion-exchange chromatography coupled with pulsed electrochemical detection as a powerful tool to evaluate carbohydrates of food Interest: Principles and Applications. International Journal of Carbohydrate Chemistry, 2012, 1-13.

23. LaCourse W. R. "Ion chromatography in food analysis," in Handbook of Food Analysis Instruments, S. Otles, 2009, Ed., pp. 161-196, CRC press, Taylor and Francis Group.

24. Ebrahimi, S., Seyed, T. B., \& Sharif, N. B. Microsatellite isolation and characterization in pomegranate (Punica granatum L.). Iranian Journal of Biotechnology, 2010, Vol. 8, No. 3, 156-163.

25. Pirseyedi, S. M., Valizadehghan, S., Mardi, M., Ghaffari, M. R., Mahmoodi, P., Zahravi, M., ... Nekoui, S. M. K. Isolation and characterization of novel microsatellite markers in pomegranate (Punica granatum L.). International Journal of Molecular Sciences, 2010, 11(5), 2010-2016.

26. Jian, Z. H., Liu, X. S., Hu, J. B., Chen, Y. H., \& Feng, J. C. Mining microsatellite markers from public expressed sequence tag sequences for genetic diversity analysis in pomegranate. Journal of genetics, 2012, 91(3), 353-358.

27. Parvaresh, M., Talebi, M., \& Sayed-Tabatabaei, B. E. Molecular diversity and genetic relationship of pomegranate (Punica granatum L.) genotypes using microsatellite markers. Scientia horticulturae, 2012, 138, 244-252.

28. Rania, J., Salwa, Z., Najib, H., Amal, B. D., Messaoud, M., \& Amel, S. H. Microsatellite polymorphism in Tunisian pomegranates (Punica granatum L.): Cultivar genotyping and identification. Biochemical Systematics and Ecology, 2012, 44, 27-35.

29. Peakall, R., \& Smouse, P. E. GenAlEx 6.5: genetic analysis in Excel. Population genetic software for teaching and research-an update. Bioinformatics, 2012, 28(19), 2537-2539.

30. Chater, J. M., Merhaut, D. J., Jia, Z., Mauk, P. A., \& Preece, J. E. Fruit quality traits of ten California-grown pomegranate cultivars harvested over three months. Scientia Horticulturae, 2018, 237, 11-19.

31. Alcaraz-Mármol, F., Nuncio-Jáuregui, N., García-Sánchez, F., Martínez-Nicolás, J. J., \& Hernández, F. Characterization of twenty pomegranate (Punica granatum L.) cultivars grown in Spain: Aptitudes for fresh consumption and processing. Scientia Horticulturae, 2017, 219, 152-160.

32. Passafiume, R., Perrone, A., Sortino, G., Gianguzzi, G., Saletta, F., Gentile, C., \& Farina, V. Chemical-physical characteristics, polyphenolic content and total antioxidant activity of three Italian-grown pomegranate cultivars. NFS Journal, 2019, 16, 9-14.

33. Beaulieu, J. C., Lloyd, S. W., Preece, J. E., Moersfelder, J. W., Stein-Chisholm, R. E., \& Obando-Ulloa, J. M. Physicochemical properties and aroma volatile profiles in a diverse collection of California-grown pomegranate (Punica granatum L.) germplasm. Food chemistry, 2015, 181, 354-364.

34. Todaro, A., Cavallaro, R., La Malfa, S., Continella, A., Gentile, A., Fischer, U., \& Spagna, G. Anthocyanin profile and antioxidant activity of freshly squeezed pomegranate (Punica granatum L.) juices of sicilian and spanish provenances. Italian Journal of Food Science, 2016, 28(3), 464-479.

35. Fanali, C., Belluomo, M. G., Cirilli, M., Cristofori, V., Zecchini, M., Cacciola, F., ... Dugo, L. Antioxidant activity evaluation and HPLC-photodiode array/MS polyphenols analysis of pomegranate juice from selected Italian cultivars: A comparative study. Electrophoresis, 2016, 37(13), 1947-1955.

36. Radunić, M., Jukić Špika, M., Goreta Ban, S., Gadže, J., Díaz-Pérez, J. C., \& MacLean, D. Physical and chemical properties of pomegranate fruit accessions from Croatia. Food Chemistry, 2015, 177, 53-60.

37. Tehranifar, A., Zarei, M., Nemati, Z., Esfandiyari, B., \& Vazifeshenas, M. R. Investigation of physico-chemical properties and antioxidant activity of twenty Iranian pomegranate (Punica granatum L.) cultivars. Scientia Horticulturae, 2010, 126(2), 180-185.

38. Mena, P., García-Viguera, C., Navarro-Rico, J., Moreno, D. A., Bartual, J., Saura, D., \& Martí, N. Phytochemical characterisation for industrial use of pomegranate (Punica granatum L.) cultivars grown in Spain. Journal of the Science of Food and Agriculture, 2011, 91(10), 1893-1906.

39. Ozgen, M., Durgaç, C., Serçe, S., \& Kaya, C. Chemical and antioxidant properties of pomegranate cultivars grown in the Mediterranean region of Turkey. Food Chemistry, 2008, 111(3), 703-706.

40. Cam, M., Hisil, Y., \& Durmaz, G. Characterisation of pomegranate juices from ten cultivars grown in Turkey. International Journal of Food Properties, 2009, 12(2), 388-395.

41. Melgarejo, P., Salazar, D. M., \& Artés, F. Organic acids and sugars composition of harvested pomegranate fruits. European Food Research and Technology, 2000, 211(3), 185-190.

42. Al-Maiman, S. A., \& Ahmad, D. Changes in physical and chemical properties during pomegranate (Punica granatum L.) fruit maturation. Food Chemistry, 2002, 76(4), 437-441.

43. Narzary, D., Rana, T. S., \& Ranade, S. A. Molecular analyses of genetic diver-sity in Indian pomegranates using RAPD, DAMD and ISSR. Pomegranate. Fruit Veg. Cereal Sci. Biotechnol, 2010, 4, 126-143.

44. Norouzi, M., Talebi, M., \& Sayed-Tabatabaei, B. E. Chloroplast microsatellite diversity and population genetic structure of Iranian pomegranate (Punica granatum L.) genotypes. Scientia horticulturae, 2012, 137, 114-120.

45. Soriano, J. M., Zuriaga, E., Rubio, P., Llácer, G., Infante, R., \& Badenes, M. L. Development and characterization of microsatellite markers in pomegranate (Punica granatum L.). Molecular breeding, 2011, 27(1), 119-128. 